\title{
Construction and Research Focus of Digital Humanities Project in Estonia
}

\author{
Hao Sun ${ }^{1, *}$, Zhaoli $\mathrm{Wu}^{2}$ \\ ${ }^{1}$ Faculty of Art and Communication, Kunming University of Science and Technology \\ ${ }^{2}$ Faculty of Art and Communication, Kunming University of Science and Technology \\ *Corresponding author. Email:housesunhao@163.com
}

\begin{abstract}
The Digital Humanities Project Construction and academic research in the Republic of Estonia are in the forefront of the world. The academic community has paid less attention to the development of digital humanities in this country. This paper introduces the representative digital humanities projects in this country, the focus of digital humanities research in China is analyzed from four aspects: linguistics, art, human geography and literature. This paper analyzes the reasons for the rapid development of digital humanities in Estonia, and provides references for the development of digital humanities in other countries.
\end{abstract}

Keywords: Digital Humanities, Estonia, research hotspots, practice

\section{INTRODUCTION}

The Republic of Estonia is located on the east coast of the Baltic Sea and has a population of only 1.315 million people and an area of only 45,227 square kilometers. However, according to the 2020 United Nations E-government Survey ${ }^{[1]}$, Estonia ranks first in the world in the Citizen Digital Participation Index. Estonia's digital transformation is comprehensive and profound, at present domestic scholars pay more attention to Estonia's network infrastructure construction, Egovernment, "E-citizen", lack of attention to the digital humanities project in Estonia. This paper introduces and analyzes the digital humanities projects and research hotspots in Estonia, and makes a brief comparison between China and Estonia in the field of digital humanities research.

\section{DIGITAL HUMANITIES PROJECT IN ESTONIA}

Estonia, which gained its independence in 1991, actively pursued an integrated cultural policy, emphasizing the important role of culture in building national identity and National Integration ${ }^{[2]}$. This policy has promoted the construction of digital humanities projects related to education, cultural heritage protection. The Representative Digital Humanities project in Estonia is presented below:

\subsection{ERNI $I^{[3]}$}

Erni is Estonia's first digital humanities project in the field of literature and cultural history, which began in 1997 and is one of Estonia's "Tiger Leap Project"to promote the informationization of education, and completed in 2001, it shows the development of Estonian literature in the 1920s and aims to provide educational institutions with digital teaching resources and e-learning tools. The printed material is from the archives of the Estonian Literature Museum, and the author's photographs are from the collections of the Estonian Literature Museum and the culture of Estonia. The project is divided into a literary chronicle, a writers'library, a portfolio of works, and a collection of photographs of writers. Users can switch among different menus to read novels, review, browse pictures, find literary terms, authors and historical events. The Erni project highlights the importance of historical context to the study of literary history and the role of readers and reviewers in shaping the interpretation and reception of literary works. The Erni project uses hyperlinks to combine seemingly unrelated, different types of text to form topic-specific text chains that make literary events clear.

\subsection{Estonian national publication Redbook ${ }^{[4]}$}

The project, which began in 2003 , was created by the 
culture of Estonia in conjunction with the achives and libraries, and was funded by the United Nations Educational, Scientific and Cultural Organization, with the aim of digitizing Estonia's precious documents, to preserve Estonia's national memory, the selected documents should reflect the national culture and personality and have a significant impact on the development of cultural history, in particular landmark works, for example, the first document with Estonian script, the first book which is completely Estonian, the first printed document on Estonian territory, the first calendar, the first magazine, the first illustrated publication, the first paper in various subject areas, etc. .

\subsection{Online Dictionary of Estonian writers $^{[5]}($ EWOD $)$}

The project was founded in 2014 by the Department of literature and drama studies, University of Tartu as a result of the Estonian state-funded project "Estonian literature in the comparative literature research paradigm"(2014-2019). The EWOD aims to collect and collate existing bibliographic data on Estonian literature and related academic research and to improve the access of international literary, cultural and research groups to information on Estonian literature. The project is divided into five sections: folklore, anthology and special issue, monograph and thesis, and author's dictionary. The author's dictionary section, arranged in alphabetical order, introduces each writer's life, experience, works, style and genre. Since multilingualism is a feature of Estonian literature, the project divides literary works into different languages.

\subsection{Ruthenia ${ }^{[6]}$}

Created in 1999 by Russian publishing company OGI and University of Tartu in Estonia, the project is entitled "Chronicle of Academic Life"in the form of a timeline, to provide the public with timely academic information such as conference lectures, scientific research achievements, scientific research experiences, academic publications. The project also includes resources from the University of Tartu and the Russian OGI publishing company, such as anthology Studing of Alexander Pushkin, and literature on Russian studies.

\subsection{Estonian film information system ${ }^{[7]}($ EFIS $)$}

The system, which is run by the non-governmental organization, a consortium of film producers, academics and others, is designed to reflect the entire Estonian film heritage since 1912. Audio-visual resources such as film footage and images, trailers and promos, scripts, and associated information such as subject, type, author, actor, production team, location, producer, distributor, copyright information, data on technical parameters of the film, and film reference books, reviews, books published on film and film makers, memories of film makers, etc. .

\subsection{Future-oriented digital humanities projects- -action plan for the digitization of cultural heritage}

As of 2018, only 10 percent of the culture of Estonia's heritage has been digitized, and the fragmentation of heritage resources and the interests of collectible institutions are major obstacles to the digitization of cultural heritage. As a result, the culture of Estonia launched the Action Plan for the digitalization of Cultural Heritage, which focuses on Cultural Heritage such as publications, photographs and films from 1900 to 1940 , the 2023 aims to make a third of the cultural heritage stored in the database digitally accessible, including 3 per cent of the documentary heritage, 32 per cent of artefacts, 60 per cent of the film and photographic heritage and 28 per cent of the print heritage. The specific project is under the responsibility of the Estonian National Museum, the National Archives of Estonia and the Estonian Literary Museum.

\section{RESEARCH FOCUS OF DIGITAL HUMANITIES IN ESTONIA}

The institutions of digital humanities in Estonia are mainly located in libraries and scientific research institutes of Universities and colleges.In the field of libraries, there are the Estonian National Museum, the National Archives of Estonia, the Estonian Museum of literature, etc. scientific research institutes include Tartu university and Tallinn university. The digital humanities centre of the Estonian Literature Museum has hosted seven Estonian annual digital humanities conferences, which are the main digital humanities academic exchange platform in Estonia.In the following,the research focus of digital humanities in Estonia is analyzed and summarized on the conference papers provided on the website of the Estonian Annual Digital Humanities Conference.

\subsection{Linguistic studies}

CORPUS compilation. While constructing the characteristic corpus, the scholars are also thinking about how to give full play to its research value. The use of corpus can break through disciplinary barriers and overcome the one-sidedness and subjectivity of traditional research. Grethe Juhkason introduces the index and marking of Estonian dialect database, and thinks that this corpus can help researchers to compare and analyze Estonian dialect from phonological, morphological and syntactic aspects ${ }^{[8]}$.Liina indström introduces the process of collection and transcription of Seto Corpus and its research value in linguistics, folklore, ethnology, anthropology, history, religion, etc. Regional, linguistic, and cultural differences have led to the 
popularity of Estonians, German, and Russian jokes in Estonia, and in 2010 a MediaWiki based joke collection of the three countries was launched, it was launched in the framework of the joint project of the Estonian Academy of Sciences and the Polish Academy of Sciences "Ideas and traditions in cultural communication". The corpus allows users to search results and analyze the interrelationships and potential evolution of texts ${ }^{[9]}$

The use of language resources. The Estonian joins two international networks, meta-share and Clarin, to provide resources with a DataCite-registered digital object identifier (Doi), which makes it as easy to reference data as it is to reference literature, the resource center has also developed tools such as Keeleliin that make it easy to perform language analysis such as morphological and syntactic analysis using plain text $\operatorname{data}^{[10]}$.

\subsection{Arts research projects}

Digital technology has deeply influenced the creation and dissemination of music, painting and other arts.

The study of digital humanities in artistic creation focuses on the analysis of musical styles and schools. Svetlana v. Kosyreva analyzes how to use modern information technology to study the genres and styles of national music ${ }^{[11]}$.Mari Sarv believes that the innovation of the database text format has given birth to the database of Estonian songs with the theme of vagrancy ${ }^{[12]}$. Raivo Kelomees believes that the original works of art were museumized, while contemporary artists use digital technology to create art, open up physical works to the audience, and record and preserve the unique experience of the artist ${ }^{[13]}$

The study of Digital Humanities in art communication focuses on the analysis of theatre experience, museum exhibition and display. Hedi-Liis Toome researched how to collect data on theater audiences and then visually analyze their theater experience. She identified 24 performance characteristics, this paper puts forward five factors that influence the experience of Drama: Aesthetic degree, entertaiment, challenge, complexity and Traditionalism ${ }^{[14]}$. Andres Uuueni studied the use of online exhibition system (VNS) display of virtual artifacts, interactive online viewing issues $^{[15]}$. Hilkka Hiiop introduces the Art Museum of Estonia system, which can digitize the image information and facilitate the input and management of information such as the restoration of cultural relics and the relationship between cultural relics ${ }^{[16]}$.

\subsection{Human geography}

For spatial visualization analysis, Kristel Uiboaed, University of Tartu, the authors studied the path of ancient map digitization, the correlation between the perceived distance expressed in text and the actual geographic distance, and the geographic information and spatial expression in language ${ }^{[17]}$.Kristel Uiboaed, Maarja-liisa Pilvik introduce the way to link traditional atlas and dialect corpus data with $\mathrm{R}$ language and QGIS software to make language change map and realize dialect data visualization analysis ${ }^{[18]}$

In the history of urban change, Juhan Pant has developed an application that combines urban street maps with historical maps to make urban development traceable in time ${ }^{[19]}$.

\subsection{Literary research projects}

Piret VIIRES studies the use of social media by Estonian writers in their literary creation, as well as the variety and periodicity of digital literature ${ }^{[20]}$. Anneli Mihkelev analyzes how Hasso Krull and Aare Pilv use hypertext links to link ancient literary texts and ancient mythological texts in a poem, and how the reader interprets the poems ${ }^{[21]}$.Marin Laak introduces the Estonian Cultural History Network ${ }^{[22]}$ presenting the author's novels, biographies, photographs, etc. on the timeline, and the problem of the compilation of literary historical materials in computational literature ${ }^{[23]}$. NASTO JÄRV makes a visual analysis of the social network of two literary works in which the fox is the main character, and explores the importance of animal images in different novels.

\section{CONCLUSION AND ENLIGHTENMENT}

In the short 20 years, Estonia has made rapid development in the field of digital humanities, which has three reasons: first, the government vigorously promotes the construction of information infrastructure and the training of information industry talents; second, the integrated cultural policy promotes the construction of digital humanities projects with the digitalization of cultural heritage as the core. third, institutions such as libraries and scientific research institutes in the country attach importance to digital humanities research, cooperation and exchanges.

While the digital humanities in Estonia are developing rapidly, there is the characteristic of periodic construction, there is often a lack of later maintenance after the completion of the project, some of the project hypertext link failure ${ }^{[24]}$, the content has not been updated with the development of the times. This reminds researchers and operators of digital humanities projects that they need continuous human and financial support, and that relevant technologies and data should be updated in a timely manner to ensure that digital humanities resources are accessible and usable. In addition, socialization, such as crowdfunding and donations, open source software, open data and other forms ${ }^{[25]}$, is also an 
effective way to promote the sustainable development of digital humanities projects.

There are great differences between China and Estonia in terms of the quantity and type of cultural resources, the level of digital infrastructure construction, laws and regulations related to intellectual property rights, etc., while Estonian digital humanities research has a strong linguistic and artistic component, Chinese digital humanities research focuses on the library science, historical geography, and other fields. China should not simply apply Estonia's digital humanities project practices, but in terms of developing technical standards, framework, management system, research and development of digital humanities research tools, data visualization, natural language processing, etc., the Digital Humanities project in Estonia is a good example.

\section{REFERENCES}

[1] UN DESA.2020 UN E-Government survey[R].Egovernment Research Center, China National Academy of Governance.2020:119.

[2] Zhou Ya.The main features of Estonia's cultural policy[J].Shandong Library Journal,2013(01):3336 .

[3] ERNI kirjanduslugu Menüüde ja sisujuhend Tehniline juhend ERNI pealehele[EB/OL].[2021-0626].http://www2.kirmus.ee/erni/erni5.html.

[4] Krista Aru, Kurmo Konsa, Tiiu Reimo, Mari Siiner.The introduction about Red Book of Estonian Publications[EB/OL].[2021-06-

26].http://web3.nlib.ee/punaneraamat/indexeng.htm

[5] About Estonian Writers' Online Dictionary[EB/OL].[2021-06-

26].https://sisu.ut.ee/ewod/about.

[6] Ruthenia.About Ruthenia[EB/OL].[2021-0626].https://www.ruthenia.ru/about/.

[7] EFDB Team.Estonian Film Database News[EB/OL].[2021-06-

26].https://www.efis.ee/en/news.

[8] Grethe Juhkason.The Digital Archives of Estonian Dialects[EB/OL].[2021-06-

26].https://www.folklore.ee/dh/en/dhe_2013/juhkas on/.

[9] Liisi Laineste.The database of East-European threenation'jokes[EB/OL].[2021-06-

26].https://www.folklore.ee/dh/en/dhe_2013/lainest $\mathrm{e} /$.

[10] Neeme Kahusk,Kadri Vider.Web services at the Center of Estonian Language Resources[EB/OL].[2021-06- 26].https://www.folklore.ee/dh/en/dhe_2015/kahus k_vider/.

[11] Svetlana V. Kosyreva.Use of digital technologies for preserving and researching music in the oral tradition of Finno-Ugric people[EB/OL].[2021-0626].https://www.folklore.ee/dh/en/dhe_2016/kosyre $\mathrm{va} /$.

[12] Mari Sarv.Calculating topics in estonian folksongs: problems with texts in nonstandard language[A].7th Estonian digital humanities conference[C],2019:7172.

[13] Raivo Kelomees.Interactive Art as a Method of Preserving and Exhibiting Physical Artworks[EB/OL].[2021-06-

26].http://www.folklore.ee/dh/en/dhe_2016/keynot e_kelomees/.

[14] Hedi-Liis Toome.The visualisation of theatrical experience[EB/OL].[2021-0626].https://www.folklore.ee/dh/en/dhe_2016/toome /.

[15] Andres Uueni.VNS:Online exhibitions system virtuaalmuuseum.ee[EB/OL].[2021-0626].https://www.folklore.ee/dh/en/dhe_2013/uueni/

[16] Hilkka Hiiop.The system for digital archiving and graphic documentation of visual data in preserving and restoring cultural heritage[EB/OL].[2021-0626].https://www.folklore.ee/dh/en/dhe_2013/hiiop/.

[17] Kristel Uiboaed,Siim Antso,Liina Lindström,Maarja-Liisa Pilvik,Mirjam Ruutma.Applying spatial data in linguistics[EB/OL].[2021-06-

26].https://www.folklore.ee/dh/en/dhe_2015/uiboae d_et_al/.

[18] Kristel Uiboaed, Maarja-Liisa Pilvik, Siim Antso, Eleri Aedmaa.Make your dialectal data shine using GIS and R[EB/OL].[2021-0626].https://www.folklore.ee/dh/en/dhe_2016/uiboae d_pilvik_antso_aedma/.

[19] Juhan Pant.Vanalinnad: Map application for historical city maps of Estonia[EB/OL].[2021-0626].https://www.folklore.ee/dh/en/dhe_2015/pant/.

[20] Piret Viires.New creative practices:alt lit-social media literature[A].7th Estonian digital humanities conference[C],2019:77.

[21] Anneli Mihkelev.Hypertextuality and intertextuality in digital age:hypertextual poems as the challenge and game of the reader's competence[A].7th Estonian digital humanities conference[C],2019:43.

[22] Kreutzwaldi sajand.About Kreutzwaldi 
sajand[EB/OL].[2021-06-

26].https://kreutzwald.kirmus.ee/et/tutvustus.

[23] Marin Laak.Content-based environments of literary history as the basis of computational literary studies[A].7th Estonian digital humanities conference[C],2019:32-33.

[24] Viires, P.Laak, M. Ephemerality in the digital world: Estonian case studies of digital literature and digital literary heritage projects. Neohelicon (2021).

[25] Ou-yang Jian,Cai Yingchun,Wang Jian.Research on the sustainability of digital humanities project.[J/OL].Library Journal:1-12. 